Article

\title{
Impact of Energy Landscapes on the Abundance of Eurasian Skylark (Alauda arvensis), an Example from North Germany
}

\author{
Nándor Csikós * and Péter Szilassi \\ Department of Physical Geography and Geoinformatics, University of Szeged, Egyetem u. 2-6, H-6722 Szeged, \\ Hungary; toto@geo.u-szeged.hu \\ * Correspondence: csikos@geo.u-szeged.hu
}

Received: 5 December 2019; Accepted: 11 January 2020; Published: 16 January 2020

check for updates

\begin{abstract}
The increasing use of biomass for energy production is reshaping landscapes into energy landscapes. Our study aims to analyze the impact of the biogas energy landscape on the abundance of Eurasian skylark. The biogas power plants have a high impact on the landscape, because of the energy crops like silage maize and rape. We analyze land-use and land-cover heterogeneity in connection with this bird species in the Federal State of Schleswig-Holstein. Three databases are used: abundance data of a typical farmland bird (Eurasian skylark), Corine land cover, and statistical land-use data from the German Agricultural Structure Survey. Several spatial analyses and statistical analyses were conducted. Generalized linear models are used with model averaging and predicted marginal effects were calculated. We estimate the changes in individuals per $\mathrm{km}^{2}$ by considering six crop types and the Shannon Diversity Index (SDI). The Eurasian skylark abundance has a significant negative correlation with the area of the inland wetlands, the Shannon Diversity Index (SDI), permanent crops, silage maize, and rape. We found significant positive correlation with the pasture, potato, and wheat. The replacement of pastures, Eurasian skylarks' preferred habitat, with energy crops, mostly silage maize, and the ongoing homogenization of the landscape, negatively affected this species' distribution in the study area.
\end{abstract}

Keywords: energy landscape; Eurasian skylark; land cover; land use; land-cover heterogeneity; crop heterogeneity

\section{Introduction}

Today, the usage of renewable energy sources is a common practice worldwide. Various renewable energy sources can be found in many countries, from the USA to China and across Europe [1-3]. Alternative energy systems are shaping the landscape, giving birth to a new term, energy landscape. Examples of ways in which these energy systems are changing the landscape include the wind turbines near the coast, biogas power plants in agricultural areas, and solar panels near roads. According to Calvert et al. [4], an energy landscape is defined as an area whose geomorphology is associated with a distinct type of energy production system, nowadays mainly renewable energy. Similar to other landscapes, they are also spatially and temporally dynamic.

The European energy sector has set up its own climate protection goals regarding greenhouse gas emissions. The European Union (EU) members decided to add more renewable energy sources to their national energy systems. The renewable energy production yield from biogas, mostly electricity [5], is $7.6 \%$ in the EU. The anaerobic co-digestion of waste and agricultural products, such as energy crops and manure, contributes to $69 \%$ of the biogas production [6].

Germany produces half of the total amount of biogas energy in the EU [6]. Most of the biogas is used to generate electricity, owing to the introduction of a renewable energy law in 2000, which was 
amended in 2004 and 2009 to encourage a boost in biogas production [7]. The law guarantees a high and constant feed-in tariff for new biogas power plants. It introduced a bonus for the use of renewable substrate materials, such as energy crops and manure [7]. More than 10,000 biogas power plants are operated mostly by local farmers with an installed capacity of $4500 \mathrm{MW}$ [7]. The transformation from agrarian landscape to energy landscape has many consequences, mostly caused by the energy crop production. The changes generated by the adoption of biomass energy can be observed in ecosystem services [8], biodiversity (fauna and flora) [9,10], land use [11-13], and landscape structure [13,14]. The cultivation of pastures and cereals to silage maize is related to increased risk of soil erosion [15], nitrogen mineralization [16,17], and release of greenhouse gases [17], as well as to changes in local biodiversity $[10,14]$. Usually, the transformation from agrarian landscape into energy landscape causes changes in landscape (land cover and land use) heterogeneity.

To analyze the links between the Eurasian skylark and land-cover and land-use (crop) heterogeneity change, we need to first investigate the cause of these changes, which is the establishment of biogas power plants and the energy crop production, like silage maize and rape. Between 2002 and 2012, in Schleswig-Holstein, there was a significant change in the landscape. The landscape transformation changed mainly food-producing landscapes to energy landscapes [13]. This relatively fast and significant change in the landscape, as well as its impacts on biodiversity, crop heterogeneity, and the abundance of farmland birds, has not been clarified yet [13].

It is important to investigate the effects of land use, land cover, crop heterogeneity, and crop structure change on the abundance of farmland birds, because many studies have indicated that the abundance of farmland birds in Europe is significantly connected with the intensity of agricultural cultivation, crop heterogeneity, and land-use change [18-22]. The Eurasian skylark Alauda arvensis is the most common farmland bird in Europe, and is also found in the Americas, Australia, and New Zealand [23]. It always nests on the ground and also spends lot of time in the air [24].

So far, just a few papers have investigated the Eurasian skylark in the Federal State of Schleswig-Holstein. No studies have analyzed the link between the Eurasian skylark abundance and the energy landscape generated by landscape transformation. Therefore, the following are the objectives of this study:

- To analyze the relationship between the abundance of Eurasian skylark, the land-cover and land-use (crop) types.

- To analyze the statistical connection between the Eurasian skylark and landscape heterogeneity by the Shannon Diversity Index (SDI).

The results of this study are expected to be valuable in analyzing and forecasting the changes in the abundance of a farmland bird species generated by biomass energy production in a typical energy landscape (North Germany). Moreover, our findings could be used as a guide for studying other situations or can be a useful tool for studying the impacts of energy-landscape-generated land-cover changes on biodiversity in other study areas.

\section{Materials and Methods}

\subsection{Study Area}

The study area is Schleswig-Holstein, the northernmost Federal State of Germany. It is bordered by the North Sea in the west, Denmark to the north, and the Baltic Sea to the east (Figure 1). The climate is formed by the sea; it is humid with an average annual precipitation of $878 \mathrm{~mm}$ and a mean annual temperature of $8.6^{\circ} \mathrm{C}$ (weather station Schleswig, data for 1981-2010, Deutscher Wetterdienst (DWD) [25]).

Schleswig-Holstein can be divided into three main landscapes. Marshlands have developed since the end of the last ice age, and these younger soils (calceric fluvisols/gleysols) are highly fertile [26]. The outwash plains ("Vorgeest" and "Hohe Geest") are characterized by less productive soils, such 
as podzols and podsolic gleysols. The Younger Moraine Hill Country area is mainly used for crop production of winter wheat (Triticum aestivum L.), barley (Hordeum vulgare L.), and oilseed rape (Brassica napus L.).

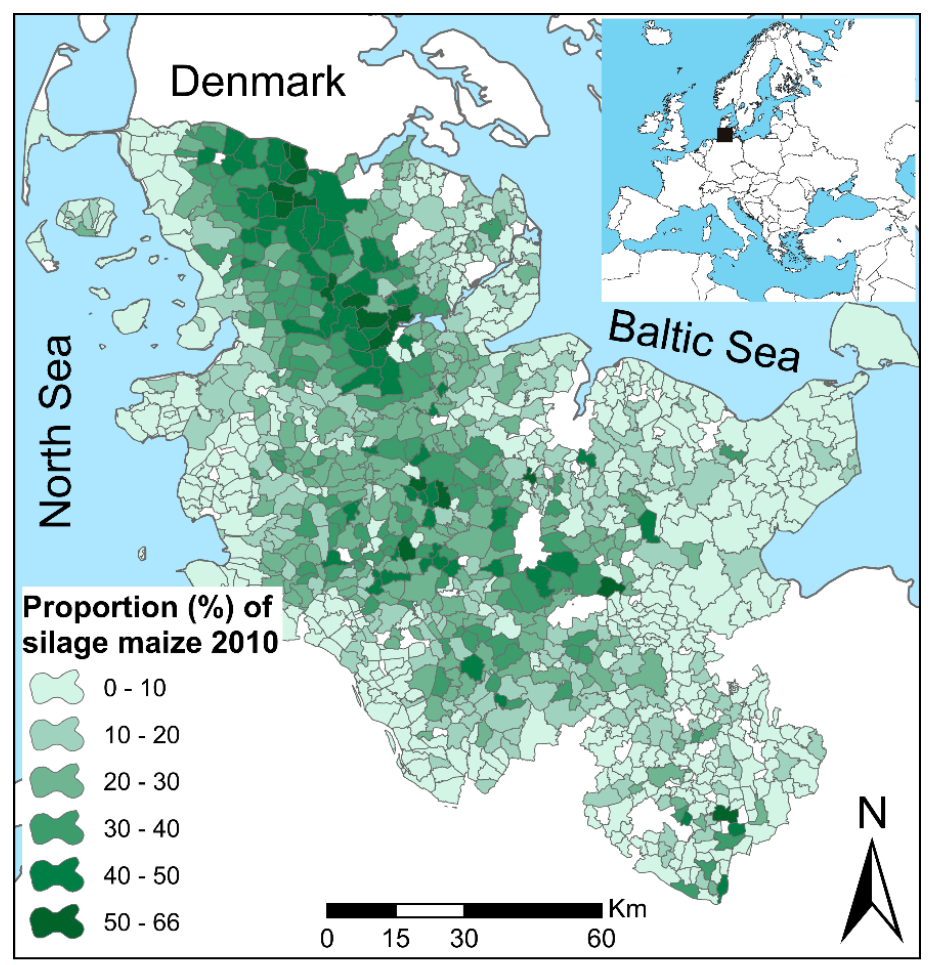

Figure 1. Proportions of the typical energy crop (silage maize) in the settlements of Schleswig-Holstein, based on Csikos et al. (2019) [13].

In Germany, the greatest production of silage maize is achieved in the northern federal states of Lower-Saxony and Schleswig-Holstein [27]. Tables 1 and 2 show the proportion of the land-cover and land-use types in Schleswig-Holstein.

Table 1. Proportion of the different land-cover types in Schleswig-Holstein, based on Corine Land Cover (CLC) 2006.

\begin{tabular}{ccc}
\hline CLC Code & Name of the CLC Category & Proportion \\
\hline 11 & Urban fabric area & $6.46 \%$ \\
12 & Industrial, commercial and transport units & $1.02 \%$ \\
13 & Mine, dump and construction sites & $0.38 \%$ \\
14 & Artificial, non-agricultural vegetated areas & $0.55 \%$ \\
21 & Arable land & $42.62 \%$ \\
23 & Pastures & $21.14 \%$ \\
24 & Heterogeneous agricultural areas & $11.46 \%$ \\
31 & Forests & $10.67 \%$ \\
32 & Shrub and/or herbaceous vegetation associations & $0.89 \%$ \\
33 & Open spaces with little or no vegetation & $0.30 \%$ \\
41 & Inland wetlands & $1.06 \%$ \\
42 & Coastal wetlands & $0.29 \%$ \\
51 & Inland waters & $3.10 \%$ \\
52 & Marine water & $0.13 \%$ \\
\hline
\end{tabular}


Table 2. Proportion of the different crop types from the total agricultural land area in Schleswig-Holstein, based on the German Agricultural Structure Survey (Agrar-Struktur-Erhebung, ASE) 2010 database.

\begin{tabular}{cc}
\hline Crop Types & Proportion \\
\hline Silage maize & $17.64 \%$ \\
Wheat & $20.68 \%$ \\
Pasture & $31.53 \%$ \\
Winter rape & $11.24 \%$ \\
Rye & $2.05 \%$ \\
Permanent crops & $0.67 \%$ \\
Potato & $0.55 \%$ \\
Sugar beet & $0.75 \%$ \\
Triticale & $0.64 \%$ \\
Other & $14.25 \%$ \\
\hline
\end{tabular}

\subsection{Data Sources and Databases}

\subsubsection{Land-Cover Database}

The European Corine land-cover (CLC) maps have been prepared using the same methodology for all EU countries [28,29]. The scale of the maps is 1:100,000, and the minimum mapping unit is 25 ha for land-cover patches with at least $100 \mathrm{~m}$ width for linear landscape elements. Mapping is repeated every six years, and thus, three assessments of land cover are available since 2000. They include 44 classes of land cover and land use, 37 of which are relevant for Germany [28] (Table A1). The study area contains 14 (level-2) CLC categories. We used the CLC dataset from 2006, because the bird field survey data was collected between 2005 and 2009 (Ornithologische Arbeitsgemeinschaft für Schleswig-Holstein 2009).

\subsubsection{Land-Use Database}

The German Agricultural Structure Survey (Agrar-Struktur-Erhebung, ASE, Hamburg, Germany 2010 was used to investigate the correlations among the Eurasian skylark abundance, land use, and crop types. This statistical survey obtained full census data on crop types and land use (Table A2). We used the census data from 2010, which were aggregated by municipality (1106 municipalities in Schleswig-Holstein).

\subsubsection{Eurasian Skylark Abundance Data}

Eurasian skylark abundance data were collected by the ornithological working group of Schleswig-Holstein and Hamburg (Ornithologische Arbeitsgemeinschaft für Schleswig-Holstein und Hamburg). The survey was supported by the ADEBAR (Der Atlas Deutscher Brutvogelarten) project between 2005 and 2009. Around 150 surveyors mapped all the breeding bird species in Schleswig-Holstein. The survey was conducted using the TK25 border grid $\left(11 \times 11 \mathrm{~km}^{2}\right)$, where the area of one grid cell is around $120 \mathrm{~km}^{2}$ [30]. Each TK25 grid cell was divided into four quadrants with a size of $5.5 \times 5.5 \mathrm{~km}^{2}$ each [31]. The federal state of Schleswig-Holstein has 646 TK25 quadrants, of which 380 quadrants were mapped (59\%). We used 281 quadrants, which had the latest abundance data from 2009 (Figure 2). We used data just from 2009, because this year fits the best to the CLC land cover (2006) and the agrarian census database from 2010. 


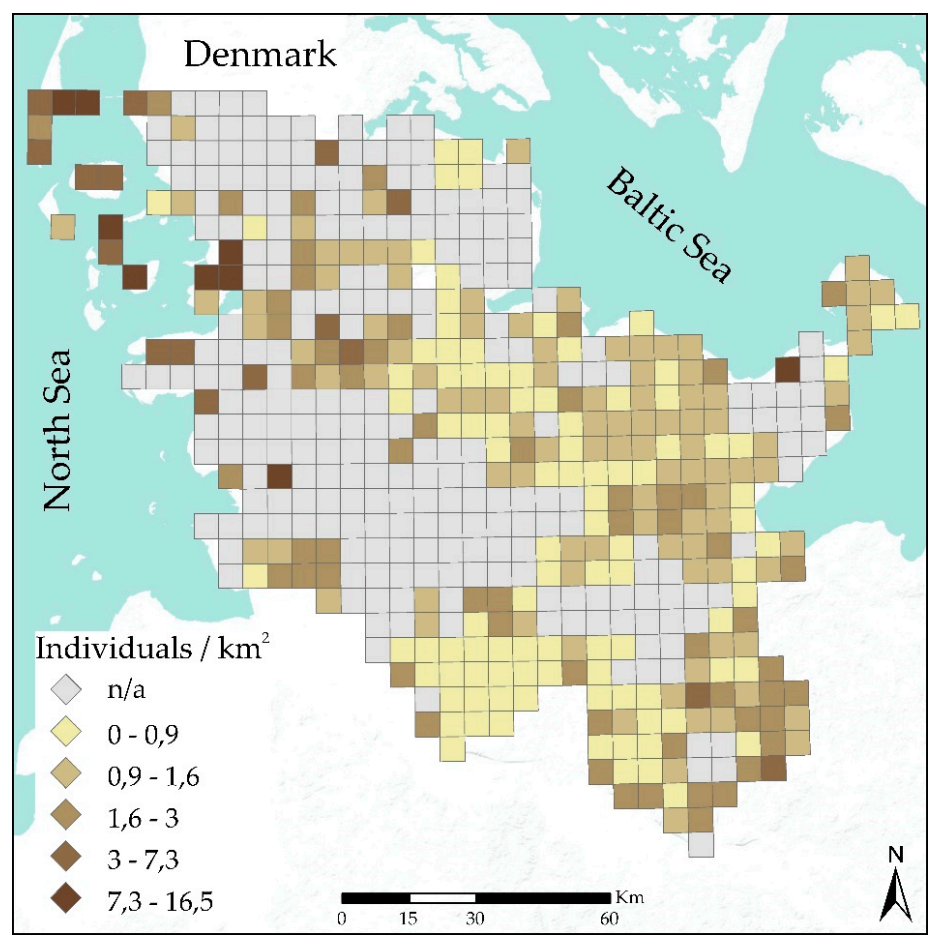

Figure 2. Density of Eurasian skylark populations in Schleswig-Holstein. Data source: Ornithologische Arbeitsgemeinschaft für Schleswig-Holstein, 2009.

\subsection{Spatial and Statistical Analyses}

For the spatial analyses, we used the ArcMap module of the ArcGis 10.3 software package. (ESRI, Redland, CA, USA) Following Uuemaa et al. (2009) [32], SDI was applied to evaluate the connection between the Eurasian skylark abundance and the landscape structure. Land cover and the crop heterogeneity index (SDI) inside the municipality polygons in ASE were calculated using a Microsoft Excel add-in [33]. The SDI represents the number of different land-use types and the relative abundance:

$$
S D I=-\sum_{i}^{m}\left(P_{i} * \ln \left(P_{i}\right)\right)
$$

where $(m)$ represents the number of different land-cover types, $P_{i}=$ the relative abundance of different land-cover types.

For the statistical analysis, we used the grid of the Eurasian skylark abundance data, the municipality layer from the ASE. We joined with the grid quadrants the municipality polygons whose centers were inside the bird survey quadrant. We conducted preliminary tests to identify any correlation between the skylark abundance and the explanatory variables, using the variance inflation factors (VIFs). The explanatory values that were not linearly connected were between VIF value of 0.44 and 8.89. We used generalized linear models (GLMs) to evaluate the effects of land-cover and land-use heterogeneity on the abundance data of Eurasian skylark (ESA). We set the skylark abundance as the response variable and the total area (ha) of the following land-use (crop) categories from ASE as explanatory variables: pasture, rape, silage maize and wheat, permanent crops, sugar beet, rye, and triticale. We used negative binominal models to take into account any overdispersion of the abundance data. We created models with all possible variations of explanatory variables, and used Akaike's information criterion to rank them with the "dredge" function from the "MuMIn" package in R [34]. We achieved model averaging for competitive models (delta AICc $<2$ ) by including the uncertainty arising from the high number of candidate models, as proposed by Burnham and Anderson [35]. We used the "LmerTest" package to estimate the significance of the variables. 
The function ggpredict from the "ggeffects" package [36] was used to compute the predicted marginal effects of the various crops based on the crops' heterogeneity in the population data of Eurasian skylark. The proportion of the crop types (ASE) and the number of skylarks per square kilometer were calculated inside the bird survey quadrants.

\section{Results}

\subsection{Correlation Between Land Cover, Land-Use Types and ESA}

We correlated ESA and the different CLC categories. Table 3 shows a summary of only the significant relationships. In the entire study area, four CLC categories show significant positive relationships with the Eurasian skylark abundance: categories of pasture land, shrub and/or herbaceous vegetation associations, and coastal wetlands. On the other hand, the skylark population is negatively correlated with the inland wetlands. The relationships with the heterogeneous agricultural areas, the inland wetlands, and the urban fabric categories are negative. SDI is negatively correlated with the Eurasian skylark population data in the entire study area ( $85 \%$ importance).

Table 3. Summary table for the CLC categories, land-use types and Shannon Diversity Index (SDI), which shows the generalized linear model (GLM) results after multimodel averaging of the best candidate models, showing the relative importance of each explanatory variable on the skylark abundance based on the estimated parameter values \pm the standard deviation.

\begin{tabular}{|c|c|c|c|c|}
\hline $\begin{array}{r}\text { Land Cover, Lar } \\
\text { Heteroger }\end{array}$ & $\begin{array}{l}\text { Use, or Landscape } \\
\text { eity Variables }\end{array}$ & Unit & $\begin{array}{c}\text { Relative } \\
\text { Importance } \\
\text { (z Value) }\end{array}$ & $\begin{array}{c}\text { Multimodel Estimate } \pm \\
\text { Standard Deviation }\end{array}$ \\
\hline \multirow{4}{*}{$\begin{array}{l}\text { Land Cover } \\
\text { (CLC Types) }\end{array}$} & Pastures & area in quadrant & $100 \%(5.194)$ & $0.0005 \pm 0.0001^{* * *}$ \\
\hline & $\begin{array}{c}\text { Shrub and/or } \\
\text { herbaceous vegetation } \\
\text { associations }\end{array}$ & area in quadrant & $100 \%(5.387)$ & $0.0024 \pm 0.0004^{* * *}$ \\
\hline & Coastal wetlands & area in quadrant & $100 \%(4.625)$ & $0.0017 \pm 0.0004^{* * *}$ \\
\hline & Inland wetlands & area in quadrant & $100 \%(3.071)$ & $-0.0024 \pm 0.0008^{* *}$ \\
\hline $\begin{array}{c}\text { Landscape } \\
\text { heterogeneity }\end{array}$ & SDI & value & $85 \%(2.104)$ & $-0.2371 \pm 0.1127^{*}$ \\
\hline \multirow{6}{*}{$\begin{array}{c}\text { Land Use } \\
\text { (ASE crop types) }\end{array}$} & Pasture & area in quadrant & $100 \%(4.322)$ & $0.0005 \pm 0.0001^{* * *}$ \\
\hline & Permanent crops & area in quadrant & $100 \%(7.254)$ & $-0.0061 \pm 0.0008^{* * *}$ \\
\hline & Silage maize & area in quadrant & $100 \%(2.185)$ & $-0.0004 \pm 0.0002^{*}$ \\
\hline & Potato & area in quadrant & $89 \%(1.991)$ & $0.0065 \pm 0.0033^{*}$ \\
\hline & Wheat & area in quadrant & $87 \%(2.239)$ & $0.0005 \pm 0.0002^{*}$ \\
\hline & Rape & area in quadrant & $87 \%(2.359)$ & $-0.0010 \pm 0.0004^{*}$ \\
\hline Crop heterogeneity & SDI & value & $100 \%(2.073)$ & $-0.3940 \pm 0.1415^{*}$ \\
\hline
\end{tabular}

In the entire study area, we observed three positive relationships with land-use types, pasture, potato, and wheat (Table 3). There are also three negative relationships, with permanent crops, silage maize, and rape. SDI has a negative relationship with ESA in the entire study area.

\subsection{Predicted Marginal Effects of Different Crop Types and Heterogeneity on the Population Data of Eurasian Skylark}

The predicted marginal effects of different crop types on the ESA in the entire study area are summarized in Figure 3. Each graph in Figure 3 shows a narrow confidence interval at the beginning, which widens gradually. According to Figure $3 \mathrm{~A}$, a maximum of 10 individuals $/ \mathrm{km}^{2}$ is predicted within $90 \%$ of the pasture proportion. Silage maize (Figure 3C) and the winter rape (Figure 3F) both have strong negative impacts on the Eurasian skylark population. On these two graphs, the upper 
confidence value stagnates or slightly decreases. The predicted marginal effect of the proportion of wheat on Eurasian skylark $/ \mathrm{km}^{2}$ increased almost linearly from 1.4 to 2.8 with a tight confidence interval until the $15 \%$ proportion of wheat.

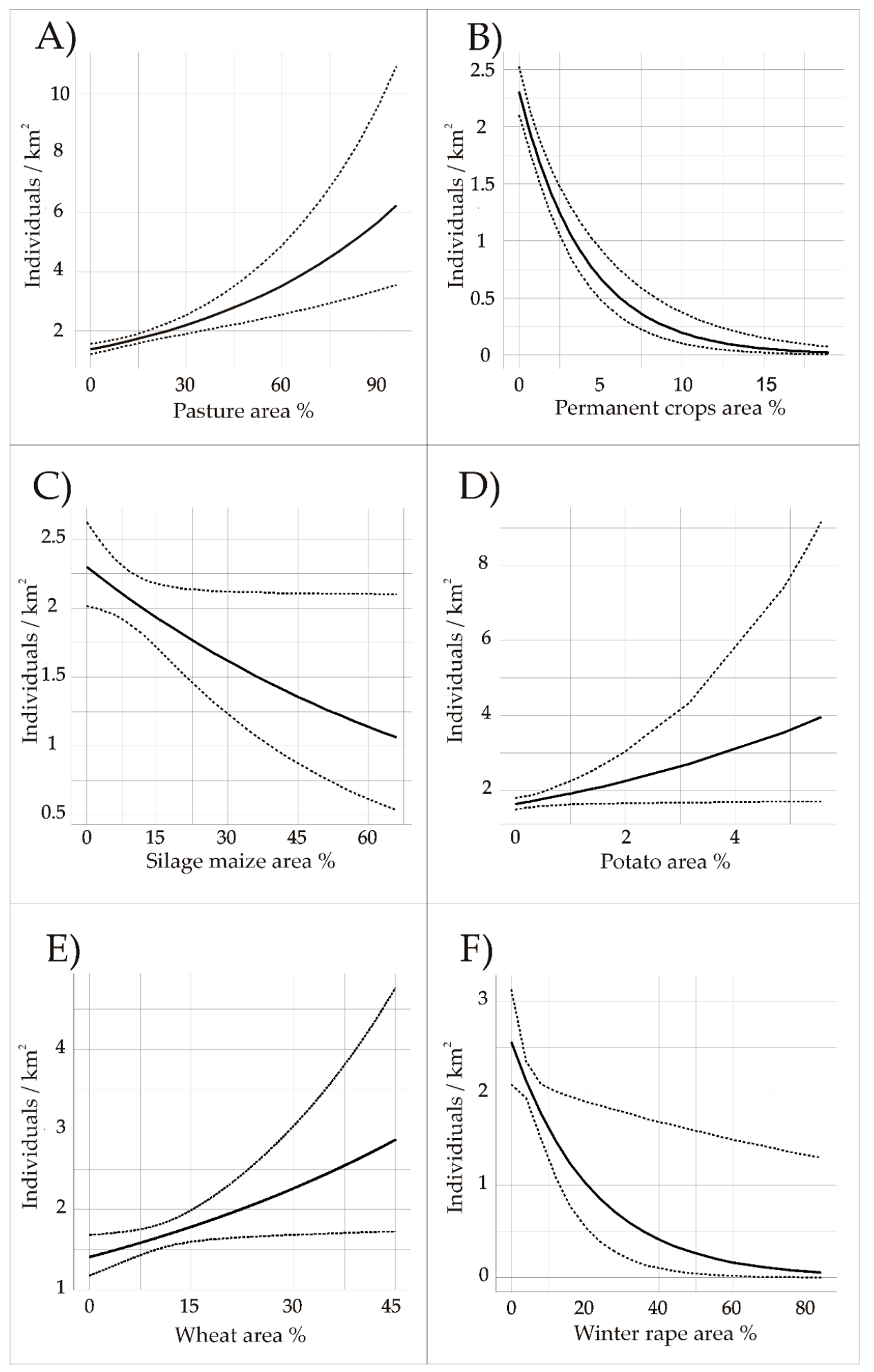

Figure 3. Predicted marginal effects between the skylark individuals / $\mathrm{km}^{2}$ and different crop types: (A) Pasture area \%; (B) Permanent crops area \%; (C) Silage maize area \%; (D) Potato area \%; (E) Wheat area \%; (F) Winter rape area \% The confidence intervals (95\%) of the prediction are shown between the dotted lines. 
The predicted marginal effects of SDI on the ESA in the entire study area are summarized in Figure 4.

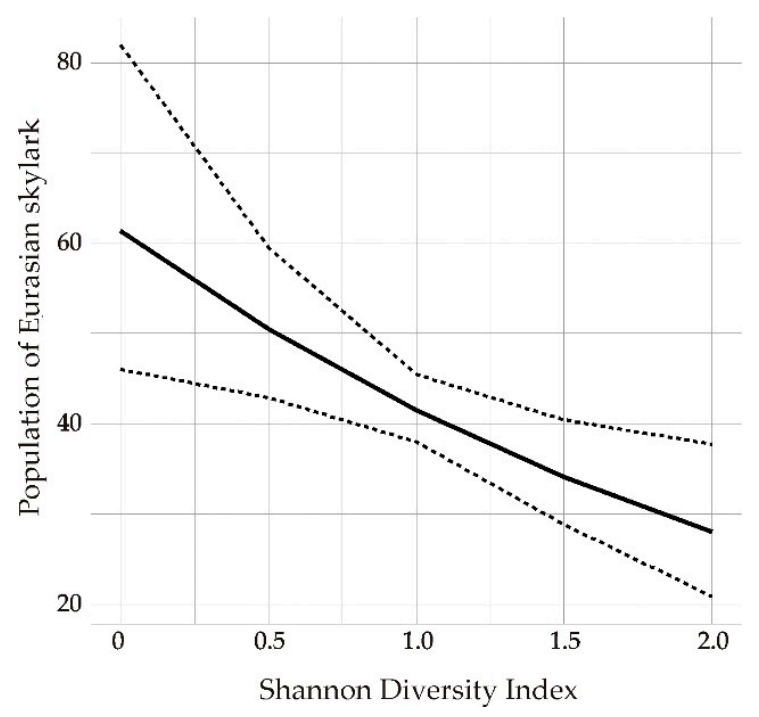

Figure 4. Predicted marginal effects of SDI on the population data of Eurasian skylark. The confidence intervals (95\%) of the prediction are shown between the dotted lines.

\section{Discussion}

The GLM results for the entire study area show a significant correlation with four land-cover categories. The pasture and the shrub and/or herbaceous vegetation association categories show a positive significant relationship. This is expected since pasture is a typical habitat of the Eurasian skylark $[23,37,38]$. The positive correlation with the shrub and/or herbaceous vegetation category is more interesting. Szilassi et al. [37] found a negative connection between this CLC category and ESA data, which they attributed to the succession process of natural grasslands. This category contains natural grassland, hedgerows, shrubs, and low vegetation. Hedgerows can be found at the edges of arable or pasture lands in Schleswig-Holstein. According to Morelli [39], marginal vegetation types (hedgerows, isolated tree, and uncultivated patches) are rather highly important as a habitat for the Eurasian skylark. We found that the coastal wetland category has a significant positive correlation with skylark abundance in the entire study area. Coastal wetland contains two subcategories in Schleswig-Holstein: salt marshes and intertidal flats. Salt marshes can be a suitable habitat for the skylark, because they include salt pastures and meadows. This result can also be explained by the data scale; the $5.5 \times 5.5 \mathrm{~km}^{2}$ quadrants can contain both a high proportion of arable land and coastal wetland in the same quadrant. This new biogas energy landscape has a strong effect on the recent land-use/land-cover changes. Due to the introduction of bioenergy plants (especially the silage maize), the area of pastures has been decreased dramatically [11]. Parallel with this process, the landscape heterogeneity also changed because of the fusion of the small parcels into homogeneous large silage maize fields without shrubs and natural grassland corridors.

We found a negative significant correlation between SDI and ESA. Our results confirm that, at the regional (CLC) scale, the increasing landscape heterogeneity has a negative effect on the population of the Eurasian skylark $[19,21,37,40,41]$. The increasing heterogeneity results in a lower abundance of the Eurasian skylark.

Based on the ASE database, we analyzed the relationship between agricultural land-use (crop) types and ESA on a large scale. The establishment of pastures has had a positive effect on the abundance of the Eurasian skylark. We found a negative correlation with the permanent crops category and this category takes the second place in the model, and therefore, has a significant impact on ESA. This negative correlation is probably due to the height and coverage of the vineyards and fruit plantations, 
which are not suitable habitats for this bird species [42,43]. In the literature, wheat is a well-known habitat type of the skylark [38,42-44]. We found a positive significant correlation between wheat and ESA. Silage maize is the next most important crop type of the study area, which also has a negative effect on ESA. We also found a negative correlation between winter rape and the Eurasian skylark in the entire study area. Strong negative impact of silage maize and winter rape can be explained based on the results of Hoffmann et al. (2018) [43]. According to these authors, these fields can provide a suitable habitat for the Eurasian skylark during the early breeding period, but later, these plants will grow too high and the ground coverage will be too much, and this area will not be suitable in the breeding periods of the year. Winter rape has the strongest negative effect, according to our multimodel estimate. The silage maize and winter rapes are the dominant land-use types of the energy landscapes. Based on Csikos et al. [13], there is a significant positive correlation between the capacity of the biogas power plants and the area of silage maize and rape.

The high heterogeneity of agricultural land, i.e., the crop types, also has a negative effect on this bird species. We found significant negative correlations in the entire study area. The relationship between crop heterogeneity and ESA has been analyzed in some previous studies. According to Chamberlain et al. (2001) [45], in England, the skylark density increased with habitat heterogeneity; nevertheless, farmland plots in the lowlands of England showed decreased skylark density with increasing habitat heterogeneity. These results suggest that the crop type is more important than the crop heterogeneity value [41]. According to Blaschke et al. [46], an increase in cultivation of bioenergy crops inside the biogas energy landscape will decrease the land availability for traditional agriculture and nature conservation.

The predicted marginal effect values are calculated based on the entire study area. Permanent crop has the largest negative effect on ESA and it can decrease the skylark individuals $/ \mathrm{km}^{2}$ value. The wheat area is a well-known habitat of the Eurasian skylark and the predicted values show that an increasing proportion of the wheat area in the landscape can increase the skylark individuals $/ \mathrm{km}^{2}$ value. The confidence interval for potato shows that potato can increase or maintain a constant individuals $/ \mathrm{km}^{2}$ value. Piha et al. [47] found that the Eurasian skylark avoided potato, and in larger open farmland areas, the skylark population density was negatively correlated with the proportion of the potato crop area. According to Dietzen et al. [48] and Kragten et al. [49], potato fields are a suitable habitat for the Eurasian skylark, because the height of this plant is less than $50 \mathrm{~cm}$, and the ground coverage proportion is low.

SDI has a negative effect on ESA, based on the predicted marginal effects. The optimum condition for the Eurasian skylark occurs when the landscape is homogeneous (one of the land uses is dominant, which supports the Eurasian skylark abundance around the birds' nests).

\section{Conclusions}

We analyzed the relationships among the abundance data of Eurasian skylark and the land-cover/land-use type, and land-cover/land-use heterogeneity in a selected study area (Schleswig-Holstein). Based on the GLM model averaging, in Schleswig-Holstein, pastures and shrub and/or herbaceous vegetation associations provided suitable habitats for the Eurasian skylark. Among the land-use types inside the agricultural areas, pasture, wheat, and potato were found to be suitable habitat types for this bird. Land cover and crop heterogeneity had negative impacts on the population of the Eurasian skylark. We identified crop types, which had positive (potato and sugar beet) or negative (silage maize, permanent crops, and rape) effects on the abundance of this bird species. Furthermore, we ranked the variables based on their importance in the GLM models. We can state that introduction of energy crops (silage maize), and the homogenization process of energy landscape have a negative effect on the population of the Eurasian skylark in the entire study area.

Author Contributions: Conceptualization, N.C. and P.S.; methodology, N.C. and P.S.; software, N.C.; formal analysis, N.C.; data curation, N.C.; writing-original draft preparation, N.C.; writing-review and editing, P.S.; visualization, N.C.; supervision, P.S. All authors have read and agreed to the published version of the manuscript. 
Funding: This research was funded by the "UNKP-19-3-SZTE-42 NEW NATIONAL EXCELLENCE PROGRAM OF THE MINISTRY FOR INNOVATION AND TECHNOLOGY" and the APC was funded by the University of Szeged Open Access Fund (grant number: 4497).

Acknowledgments: We express our sincere thanks to Bernd Koop (Ornithologische Arbeitsgemeinschaft für Schleswig-Holstein und Hamburg) for providing the abundance data of the Eurasian skylark. We thank the anonymous referees for their valuable recommendations and suggestions.

Conflicts of Interest: The authors declare no conflict of interest.

\section{Appendix A Appendix}

Table A1. CLC nomenclature and CLC categories, Source: Bossard et al. 2000 [50], Cole et al. 2018 [51], Kosztra et al. 2019 [52].

\begin{tabular}{|c|c|c|}
\hline $\begin{array}{l}\text { CLC } \\
\text { (code) }\end{array}$ & $\begin{array}{l}\text { Name of the CLC } \\
\text { Category (Model) }\end{array}$ & Description \\
\hline 11 & Urban fabric area & $\begin{array}{l}\text { Areas mainly occupied by dwellings and buildings used by } \\
\text { administrative/public utilities, including their connected areas } \\
\text { (associated lands, approach road network, and parking lots). }\end{array}$ \\
\hline 12 & $\begin{array}{l}\text { Industrial, commercial, } \\
\text { and transport units }\end{array}$ & $\begin{array}{l}\text { Areas mainly occupied by industrial activities of manufacturing, } \\
\text { trade, financial activities and services, transport infrastructures for } \\
\text { road traffic and rail networks, airport installations, river and sea } \\
\text { port installations, including their associated lands and access } \\
\text { infrastructures. Includes industrial livestock rearing facilities. }\end{array}$ \\
\hline 14 & $\begin{array}{l}\text { Artificial, } \\
\text { non-agricultural } \\
\text { vegetated areas }\end{array}$ & $\begin{array}{l}\text { Areas voluntarily created for recreational use. Includes green or } \\
\text { recreational and leisure urban parks, and sport and leisure facilities. }\end{array}$ \\
\hline 22 & Permanent crops & $\begin{array}{l}\text { All surfaces occupied by permanent crops not under a rotation } \\
\text { system. Includes ligneous crops of standard cultures for fruit } \\
\text { production, such as extensive fruit orchards, olive groves, chestnut } \\
\text { groves, walnut groves shrub orchards such as vineyards and some } \\
\text { specific low-system orchard plantation. }\end{array}$ \\
\hline 23 & Pastures & $\begin{array}{l}\text { Lands that are permanently used (at least for } 5 \text { years) for fodder } \\
\text { production. Includes natural or sown herbaceous species, } \\
\text { unimproved or lightly improved meadows, and grazed or } \\
\text { mechanically harvested meadows. Regular agriculture impact } \\
\text { influences the natural development of natural herbaceous species } \\
\text { composition. }\end{array}$ \\
\hline 24 & $\begin{array}{l}\text { Heterogeneous } \\
\text { agricultural areas }\end{array}$ & $\begin{array}{l}\text { Areas of annual crops associated with permanent crops on the same } \\
\text { parcel. Annual crops cultivated under forest trees. Areas of annual } \\
\text { crops. Meadows and/or permanent crops that are juxtaposed. } \\
\text { Landscapes where crops and pastures are intimately mixed with } \\
\text { natural vegetation or natural areas. }\end{array}$ \\
\hline 31 & Forests & $\begin{array}{l}\text { Areas occupied by forests and woodlands with a vegetation pattern } \\
\text { composed of native or exotic coniferous and/or broad-leaved trees } \\
\text { and which can be used for the production of timber or other forest } \\
\text { products. The forest trees are under normal climatic conditions } \\
\text { higher than } 5 \mathrm{~m} \text { with a canopy closure of at least } 30 \% \text {. }\end{array}$ \\
\hline 32 & $\begin{array}{l}\text { Shrub and/or herbaceous } \\
\text { vegetation associations }\end{array}$ & $\begin{array}{l}\text { Grasslands under no or moderate human influence. } \\
\text { Low-productivity grasslands. Often situated in areas of rough, } \\
\text { uneven ground, steep slopes. Vegetation with low and closed cover } \\
\text { dominated by bushes, shrubs, dwarf shrubs, and herbaceous plants, } \\
\text { forming a climax stage of development. Transitional bushy and } \\
\text { herbaceous vegetation with occasional scattered trees. Can } \\
\text { represent woodland degradation, forest regeneration, } \\
\text { recolonization, or natural succession. }\end{array}$ \\
\hline
\end{tabular}


Table A1. Cont.

\begin{tabular}{|c|c|c|}
\hline $\begin{array}{l}\text { CLC } \\
\text { (code) }\end{array}$ & $\begin{array}{l}\text { Name of the CLC } \\
\text { Category (Model) }\end{array}$ & Description \\
\hline 41 & Inland wetlands & $\begin{array}{l}\text { Areas flooded or liable to flooding during the great part of the year } \\
\text { by fresh, brackish, or standing water with specific vegetation } \\
\text { coverage made of low shrub. Semi-ligneous or herbaceous species. } \\
\text { Includes water fringe vegetation of lakes, rivers, and brooks. Highly } \\
\text { oligotrophic and strongly acidic communities composed mainly of } \\
\text { sphagnum growing on peat and deriving moistures of raised bogs } \\
\text { and blanket bogs. }\end{array}$ \\
\hline 42 & Coastal wetlands & $\begin{array}{l}\text { Areas submerged by high tides at some stage of the annual tidal } \\
\text { cycle. Includes salt meadows, faces of saltmarsh grass meadows, } \\
\text { transitional or not to other communities, vegetation occupying } \\
\text { zones of varying salinity and humidity, sands and muds submerged } \\
\text { for part of every tide devoid of vascular plants, active or recently } \\
\text { abandoned salt-extraction evaporation basins. }\end{array}$ \\
\hline
\end{tabular}

Table A2. ASE database nomenclature, source: Hessisches Statistisches Landesamt, 2016 [53].

\begin{tabular}{cc}
\hline Crop Type & Description \\
\hline Oat & Cereal for grain production including seed production. \\
\hline Permanent crops & $\begin{array}{r}\text { Tree and berry orchards, nuts, vineyards, tree nurseries and Christmas tree crops, and } \\
\text { poplar plants outside the forest. }\end{array}$ \\
\hline Pasture & $\begin{array}{c}\text { Permanent pasture includes all grassland areas outside of crop rotation-without } \\
\text { interruption by other cultures-are used and for fodder or litter production or for } \\
\text { grazing are determined. Permanent grassland areas are accordingly meadows, } \\
\text { mowing pastures, and pastures. }\end{array}$ \\
\hline Potato & Root crops category, potato fields. \\
\hline Rape & Oil seed category, winter rape, and suitable for feeding biogas power stations. \\
\hline Silage maize & Green forage category, used for feeding biogas power stations or livestock. \\
\hline Whar beet & Root crops category, used for feeding biogas power stations or livestock. \\
\hline
\end{tabular}

\section{References}

1. Sahoo, K.; Mani, S.; Das, L.; Bettinger, P. GIS-based assessment of sustainable crop residues for optimal siting of biogas plants. Biomass Bioenergy 2018, 110, 63-74. [CrossRef]

2. Van der Horst, D.; Martinat, S.; Navratil, J.; Dvorak, P.; Chmielova, P. What can the location of biogas plants tell us about agricultural change? A Case Study from the Czech Republic. DETUROPE 2018, 10, $33-52$.

3. Gao, M.; Wang, D.; Wang, H.; Wang, X.; Feng, Y. Biogas potential, utilization and countermeasures in agricultural provinces: A case study of biogas development in Henan Province, China. Renew. Sustain. Energy Rev. 2019, 99, 191-200. [CrossRef]

4. Calvert, K.; Greer, K.; Maddison-MacFadyen, M. Theorizing energy landscapes for energy transition management: Insights from a socioecological history of energy transitions in Bermuda. Geoforum 2019, 102, 191-201. [CrossRef]

5. EEA. Renewable Energy in Europe 2017. Recent Growth and Knock-On Effects. EEA Report No 3/2017. Available online: https://www.eea.europa.eu/publications/renewable-energy-in-europe-2017 (accessed on 14 January 2020).

6. EC (European Commission). Optimal Use of Biogas from Waste Streams. An Assessment of the Potential of Biogas from Digestion in the EU beyond 2020-European Commission. Available online: https:/ec.europa.eu/energy/en/studies/optimal-use-biogas-waste-streams-assessment-potentialbiogas-digestion-eu-beyond-2020 (accessed on 9 May 2018). 
7. Scheftelowitz, M.; Becker, R.; Thrän, D. Improved power provision from biomass: A retrospective on the impacts of German energy policy. Biomass Bioenergy 2018, 111, 1-12. [CrossRef]

8. Lupp, G.; Steinhäußer, R.; Starick, A.; Gies, M.; Bastian, O.; Albrecht, J. Forcing Germany's renewable energy targets by increased energy crop production: A challenge for regulation to secure sustainable land use practices. Land Use Policy 2014, 36, 296-306. [CrossRef]

9. Schleupner, C.; Link, P.M. Potential impacts on important bird habitats in Eiderstedt (Schleswig-Holstein) caused by agricultural land use changes. Appl. Geogr. 2008, 28, 237-247. [CrossRef]

10. Brandt, K.; Glemnitz, M. Assessing the regional impacts of increased energy maize cultivation on farmland birds. Environ. Monit. Assess. 2014, 186, 679-697. [CrossRef]

11. Lüker-Jans, N.; Simmering, D.; Otte, A. The impact of biogas plants on regional dynamics of permanent grassland and maize area-The example of Hesse, Germany (2005-2010). Agric. Ecosyst. Environ. 2017, 241, 24-38. [CrossRef]

12. Laggner, B.; Orthen, N.; Osterburg, B.; Röder, N. Ist die zunehmende Biogasproduktion die alleinige Ursache für den Grünlandschwund in Deutschland?-Eine Analyse von georeferenzierten Daten zur Landnutzung. Raumforsch. Raumordn. 2014, 72, 195-209. [CrossRef]

13. Csikos, N.; Schwanebeck, M.; Kuhwald, M.; Szilassi, P.; Duttmann, R. Density of Biogas Power Plants as An Indicator of Bioenergy Generated Transformation of Agricultural Landscapes. Sustainability 2019, 11, 2500. [CrossRef]

14. Link, P.M.; Schleupner, C. Agricultural land use changes in Eiderstedt: Historic developments and future plans. Coastline Rep. 2007, 9, 928-2734.

15. Duttmann, R.; Hassenpflug, W.; Bach, M.; Lungershausen, U.; Frank, J.-H. Winderosion in Schleswig-Holstein; Landesamt für Landwirtschaft, Umwelt und ländliche Räume des Landes Schleswig-Holstein (LLUR): Hamburg, Germany, 2011; ISBN 978-3-937937-56-4.

16. Svoboda, N.; Taube, F.; Kluß, C.; Wienforth, B.; Kage, H.; Ohl, S.; Hartung, E.; Herrmann, A. Crop production for biogas and water protection-A trade-off? Agric. Ecosyst. Environ. 2013, 177, 36-47. [CrossRef]

17. KLU. Biogaserzeugung und-nutzung: Ökologische Leitplanken für die Zukunft Vorschläge der Kommission Landwirtschaft beim Umweltbundesamt (KLU); Dessau-Roßlau, Germany, 2013. Available online: https://www.umweltbundesamt.de/sites/default/files/medien/378/publikationen/biogaserzeugung und_-nutzung_oekologische_leitplanken_fuer_die_zukunft.pdf (accessed on 11 March 2019).

18. Gil-Tena, A.; De Cáceres, M.; Ernoult, A.; Butet, A.; Brotons, L.; Burel, F. Agricultural landscape composition as a driver of farmland bird diversity in Brittany (NW France). Agric. Ecosyst. Environ. 2015, 205, 79-89. [CrossRef]

19. Gottschalk, T.K.; Dittrich, R.; Diekötter, T.; Sheridan, P.; Wolters, V.; Ekschmitt, K. Modelling land-use sustainability using farmland birds as indicators. Ecol. Indic. 2010, 10, 15-23. [CrossRef]

20. Moreira, F.; Beja, P.; Morgado, R.; Reino, L.; Gordinho, L.; Delgado, A.; Borralho, R. Effects of field management and landscape context on grassland wintering birds in Southern Portugal. Agric. Ecosyst. Environ. 2005, 109, 59-74. [CrossRef]

21. Guerrero, I.; Morales, M.B.; Oñate, J.J.; Geiger, F.; Berendse, F.; de Snoo, G.; Eggers, S.; Pärt, T.; Bengtsson, J.; Clement, L.W.; et al. Response of ground-nesting farmland birds to agricultural intensification across Europe: Landscape and field level management factors. Biol. Conserv. 2012, 152, 74-80. [CrossRef]

22. Verhulst, J.; Báldi, A.; Kleijn, D. Relationship between land-use intensity and species richness and abundance of birds in Hungary. Agric. Ecosyst. Environ. 2004, 104, 465-473. [CrossRef]

23. Cramp, S. The Birds of the Western Palearctic; Oxford University Press: Oxford, UK, 1988; Volume 5, ISBN 9780198575085.

24. Donald, P.F.; Green, R.E.; Heath, M.F. Agricultural intensification and the collapse of Europe's farmland bird populations. Proc. R. Soc. B Biol. Sci. 2001, 268, 25-29. [CrossRef]

25. DWD Weather of Schleswig 1981-2010. Available online: https://www.dwd.de/EN/weather/weather_climate_ local/schleswigholstein_hamburg/schleswig/_node.html (accessed on 13 October 2019).

26. FAO. FAO World Reference Base for Soil Resources 2014 International Soil Classification System for Naming Soils and Creating Legends for Soil Maps; Update 2015 World Soil Resources Reports; FAO: Rome, Italy, 2014.

27. Schmidt, C. Entwicklung der Anbauflächen für Silomais seit 1999. Available online: https:/tu-dresden.de/bu/architektur/ila/lp/ressourcen/dateien/Forschung/abgeschlossene-forschung/ monitoring-kula-kartenserie-arbeitspaket2/karte5?lang=de (accessed on 11 March 2019). 
28. EEA and ETC-TE CLC Update CLC 2000 Project. Technical Guidelines. Final Version. Available online: http://land.copernicus.eu/user-corner/technical-library/techrep89.pdf (accessed on 9 May 2018).

29. EEA. The Thematic Accuracy of CLC 2000. Assessment Using LUCAS (Land Use/Cover Area Frame Statistical Survey); European Environment Agency: Coppenhagen, Denmark, 2006.

30. Südbeck, P.; Andretzke, H.; Fischer, S.; Gedeon, K.; Schikore, T.; Schröder, K.; Sudfeldt, C. Methodenstandards zur erfassung der Brutvögel Deutschlands; Buch: Berlin, Germany, 2005; ISBN 300015261X.

31. Brendt, R.K.; Koop, B.; Struwe-Juhl, B. Vogelwelt Schleswig-Holsteins, 2nd ed.; Wachholz Verlag: Neumünster, Germany, 2005.

32. Uuemaa, E.; Antrop, M.; Roosaare, J.; Marja, R.; Mander, Ü. Landscape Metrics and Indices: An Overview of Their Use in Landscape Research. Living Rev. Landsc. Res. 2009, 3, 3. [CrossRef]

33. Statistical Service Centre (SSC) Microsoft Excel Add-In Diversity Calculator, Reading University, 2010. Available online: http://www.geo.u-szeged.hu/ \{\}toto/Excel_Diversity_add-in/(accessed on 15 January 2020).

34. Barton, K. Package MuMIn, version 1.43.15; 2015. Available online: https://cran.r-project.org/web/packages/ MuMIn/MuMIn.pdf (accessed on 15 September 2019).

35. Burnham, K.P.; Anderson, D.R. Model Selection and Multi-Model Inference: A Practical Information-Theoretical Approach; Springer: Berlin/Heidelberg, Germany, 2002; Volume 3, pp. 2-3.

36. Lüdecke, D. ggeffects: Tidy Data Frames of Marginal Effects from Regression Models. J. Open Source Softw. 2018, 3, 772. [CrossRef]

37. Szilassi, P.; Csikos, N.; Galle, R.; Szep, T. Recent and Predicted Changes in Habitat of the Eurasian Skylark Alauda arvensis Based on the Link between the Land Cover and the Field Survey Based Abundance Data. Acta Ornithol. 2019, 54, 59-71. [CrossRef]

38. Hoffmann, J.; Wittchen, U.; Stachow, U.; Berger, G. Moving Window Abundance-A method to characterise the abundance dynamics of farmland birds: The example of Skylark (Alauda arvensis). Ecol. Indic. 2016, 60, 317-328. [CrossRef]

39. Morelli, F. Relative importance of marginal vegetation (shrubs, hedgerows, isolated trees) surrogate of HNV farmland for bird species distribution in Central Italy. Ecol. Eng. 2013, 57, 261-266. [CrossRef]

40. Berg, Å.; Wretenberg, J.; Zmihorski, M.; Hiron, M.; Pärt, T. Linking occurrence and changes in local abundance of farmland bird species to landscape composition and land-use changes. Agric. Ecosyst. Environ. 2015, 204, 1-7. [CrossRef]

41. Redlich, S.; Martin, E.A.; Wende, B.; Steffan-Dewenter, I. Landscape heterogeneity rather than crop diversity mediates bird diversity in agricultural landscapes. PLoS ONE 2018, 13, e0200438. [CrossRef]

42. Praus, L.; Weidinger, K. Breeding Biology of Skylarks Alauda arvensis in Maize and Other Crop Fields. Acta Ornithol. 2015, 50, 59-68. [CrossRef]

43. Hoffmann, J.; Wittchen, U.; Berger, G.; Stachow, U. Moving window growth-A method to characterize the dynamic growth of crops in the context of bird abundance dynamics with the example of Skylark (Alauda arvensis). Ecol. Evol. 2018, 8, 8880-8893. [CrossRef]

44. Morris, A.J.; Holland, J.M.; Smith, B.; Jones, N.E. Sustainable Arable Farming For an Improved Environment (SAFFIE): Managing winter wheat sward structure for Skylarks Alauda arvensis. IBIS 2004, 146, 155-162. [CrossRef]

45. Chamberlain, D.E.; Wilson, A.M.; Browne, S.J.; Vickery, J.A. Effects of habitat type and management on the abundance of skylarks in the breeding season. J. Appl. Ecol. 1999, 36, 856-870. [CrossRef]

46. Blaschke, T.; Biberacher, M.; Gadocha, S.; Schardinger, I. "Energy landscapes": Meeting energy demands andhuman aspirations. Biomass Bioenergy 2013, 55, 3-16. [CrossRef] [PubMed]

47. Piha, M.; Pakkala, T.; Tiainen, J. Habitat preferences of the Skylark Alauda arvensis in southern Finland. Ornis Fenn. 2003, 80, 97-110.

48. Dietzen, C.; Edwards, P.J.; Wolf, C.; Ludwigs, J.-D.; Luttik, R. Focal species of birds in European crops for higher tier pesticide risk assessment. Integr. Environ. Assess. Manag. 2014, 10, 247-259. [CrossRef]

49. Kragten, S.; Trimbos, K.B.; de Snoo, G.R. Breeding skylarks (Alauda arvensis) on organic and conventional arable farms in The Netherlands. Agric. Ecosyst. Environ. 2008, 126, 163-167. [CrossRef]

50. Bossard, M.; Feranec, J.; Otahel, J. CORINE Land Cover Technical Guide-Addendum 2000 Part I State-of-Play Production Methods of the CORINE Land Cover Database; European Environment Agency: Coppenhagen, Denmark, 2000. 
51. Cole, B.; Smith, G.; Balzter, H. Acceleration and fragmentation of CORINE land cover changes in the United Kingdom from 2006-2012 detected by Copernicus IMAGE2012 satellite data. Int. J. Appl. Earth Obs. Geoinf. 2018, 73, 107-122. [CrossRef]

52. Kosztra, B.; Büttner, G.; Hazeu, G.; Arnorld, S. Updated CLC Illustrated Nomenclature Guidelines; European Environment Agency: Coppenhagen, Denmark, 2019.

53. Statistisches Landesamt, H. Agrarstrukturerhebung 2016 Methoden und Vorbemerkungen; 2016., Wiesbaden, Gemany. Available online: https://www.destatis.de/GPStatistik/servlets/MCRFileNodeServlet/HEHeft_ derivate_00006795/CIV9_13_3j16_a.pdf;jsessionid=0EF69FB253A89C34CED45195E4AD855C (accessed on 20 November 2019).

(C) 2020 by the authors. Licensee MDPI, Basel, Switzerland. This article is an open access article distributed under the terms and conditions of the Creative Commons Attribution (CC BY) license (http://creativecommons.org/licenses/by/4.0/). 